\title{
Комплексний розвиток технічної та фізичної підготовленості тенісисток 7-8 років
}

\author{
Олег Шевченко \\ Святослав Коваль \\ Максим Мерзлікін
}

Харківська державна академія фізичної культури,

Харків, Україна

\begin{abstract}
Мета: дослідити зміни показників технічної та фізичної підготовленості тенісисток 7-8 років під впливом занять за програмою ДЮСШ.

Матеріал і методи: теоретичний аналіз та узагальнення науково-методичних літературних джерел; тестування технічної та фізичної підготовленості, педагогічний експеримент, методи математичної статистики. У дослідженні брали участь 12 дівчат віком 7-8 років групи початкової підготовки 2 року навчання.

Результати: отримані достовірні зміни показників фізичної підготовленості тенісисток у метанні тенісного м'яча на дальність на 39,8\% ( $t=3,70, p<0,01)$, у хваті гімнастичної палиці, що падає, на 12,7\% $(t=5,00, p<0,001)$, у човниковому бігу у 5 напрямах з ракетками «Віяло» на 8,9\% (t=2,40, p<0,05). В інших контрольних вправах були отримані позитивні зміни, але не мали достовірних результатів ( $p>0,05)$. В технічній підготовленості отримані позитивні достовірні зміни у вправах: удар з відскоку від стінки на 33,3\% (t=2,20, p<0,05) та в ударі з відскоку через сітку з кошика тренера на 56,4\% (t=2,70, p<0,05). Правильно підібрані вправи з фізичної підготовки дали змогу тенісисткам своєчасно підходити до м'яча для виконання удару і покращити результати тестування. Виявлено, що покращення показників у стрибках в довжину, метання тенісного м'яча на дальність і точність сприяло підвищенню значимості кореляційних зв'язків до середнього та високого рівнів показників в ударах з відскоку від стінки та через сітку, в подачі.
\end{abstract}

Висновки: впровадження методики комплексного розвитку фізичних якостей та технічної підготовленості за програмою ДЮСШ сприяло достовірним змінам показників. Визначилися шляхи для подальшого удосконалення швидкісних, швидкісно-силових та координаційних здібностей, подачі та ударів по м'ячу тенісисток.

Ключові слова: тенісистки, фізична підготовленість, показники, технічні прийоми.

\section{Вступ}

В сучасних умовах спортивної підготовки ефективне удосконалення підготовленості юних тенісистів залишається однією з актуальних проблем. Для досягнення успіхів в тенісі спортсменам необхідна належна фізична, технічна, тактична та психологічна підготовка, високий рівень яких закладається вже на початковому етапі навчання.

Однією з найважливіших тенденцій розвитку сучасного тенісу $€$ пошук нових, більш ефективних засобів і методів підготовки. У своїх наукових працях фахівці стверджують, що розвинені фізичні якості $€$ вкрай необхідними для успішної гри в теніс [7, 9].

В програмах підготовки тенісистів описується структура тренувального процесу та послідовність виконання вправ на етапі початкової підготовки $[4,11,12]$. Аналіз методик підготовки дітей на початковому етапі в тенісі вказує на спрямованість тренувального процесу на розвиток фізичних якостей, особливо швидкісного та швидкісно-силового характеру, координаційних здібностей, оволодіння основними елементами гри та поступове включення у змагальну діяльність серед дітей свого віку сприяє подальшому підвищенню рівня підготовленості спортсменів $[8,13]$.

Для визначення рівня фізичної та технічної підготовленості тенісистів, зокрема, на етапі початкової підготов- ки використовується низка тестів за програмою ДЮСШ $[1,5]$.

У той же час, пошук ефективних методик підготовки в тенісі на етапі початкової підготовки сприяє більш міцному фундаменту підготовленості спортсменів та високих результатів в подальшій змагальній діяльності, що вказує на актуальність вибраної теми.

Зв'язок дослідження з науковими та практичними завданнями, планами, програмами. Дослідження проводилося відповідно до ініціативної теми НДР кафедри спортивних та рухливих ігор Харківської державної академії фізичної культури «Удосконалення навчально-тренувального процесу в спортивних іграх» на 2019-2023 рр. (номер державної реєстрації: 0119U101644).

Мета дослідження - дослідити зміни показників технічної та фізичної підготовленості тенісисток 7-8 років під впливом занять за програмою ДЮСШ.

\section{Завдання дослідження:}

1. Визначити рівень технічної і фізичної підготовленості тенісисток.

2. Дослідити зміни показників технічної і фізичної підготовленості тенісисток під впливом занять за програмою ДЮСШ.

3. Встановити взаємозв'язки між показниками технічної і фізичної підготовленості тенісисток 7-8 років. 


\section{Матеріал і методи дослідження}

У дослідженні брали участь 12 дівчат віком 7-8 років групи початкової підготовки 2 року навчання. Дослідження проводилися протягом 5 місяців на базі тенісного клубу «Хвиля» м. Харків.

Тестування показників технічної підготовленості проводилося за вправами: удари по м'ячу з відскоку об стінку, удари по м'ячу з відскоку через сітку з кошиком, подача через сітку, удари зльоту через сітку. Для визначення показників фізичної підготовленості юних тенісисток були використані контрольні вправи: метання тенісного м'яча на дальність, біг 18 м; човниковий біг у 5 напрямах; хват гімнастичної палиці, що падає; стрибок у довжину з місця; кидок тенісного м'яча у квадрати провідною рукою.

У ході педагогічного експерименту були враховано результати попередніх тестувань рівня підготовленості спортсменок та визначено методика підготовки тенісисток. У методиці застосовувалися вправи та методи, які сприяли комплексному підвищенню фізичної та технічної підготовленості спортсменок. Застосовувалася методика за програмою ДЮСШ $[1,4]$ для спортсменок групи початкової підготовки 2 року навчання тенісу. Тренування проводилося 3 рази на тиждень тривалістю 1,5 години. В кінці підготовчої та на початку основної частини тренування виконувалися вправи для комплексного розвитку координаційних, швидкісних здібностей і технічної підготовленості спортсменок. В кінці заняття проводилося комплексне тренування швидкісно-силових здібностей та витривалості разом з удосконаленням технічної підготовленості тенісисток. Заняття проводилися з застосуванням ігрового методу з використанням рухливих ігор.

Для розвитку фізичної підготовленості використовувалися вправи для швидкісних та швидкісно-силових здібностей, а саме, різноманітні стрибки: в довжину, в сторону-вверх, вверх, вверх-назад з місця, з розбігу, різноманітні стрибки зі скакалкою; кидки тенісного м'яча на дальність, старти з різних положень з ракетками, бігові вправи з прискоренням; для координаційних здібностей - ловля тенісного м'яча в різних положеннях на початковому моменті та у верхній точці його відскоку, кидок тенісного м'яча на влучність з різних дистанцій, вправи з м'ячами та ракетками на координаційній драбині; для витривалості - звичайний тривалий біг, інтервальний біг боком та спиною вперед з прискоренням, для розвитку сили - вправи з еспандером для кисті, метання набивного м'яча рухами, які схожі на виконання ударів зліва, справа, подачі, згинання-розгинання рук в упорі лежачи. Спортсменки після оволодіння вправами виконували завдання - тренування ігровим та змагальним методом.

У технічній підготовці приділялася увага підходу до м'яча, виконанню ударів та переміщенню до вихідної позиції, у спеціально-підготовчих засобах застосовувалися вправи з м'ячем на місці і в русі, виконувалися різноманітні удари ракеткою по м'ячу з відскоку, зльоту, подачі. Тенісистки вчилися тримати м'яч у грі, вести гру на рахунок.

\section{Результати дослідження}

Первинне педагогічне тестування виявило, що показники розвитку тенісисток 7-8 років мають задовільні результати для цього віку відповідно з нормативами ДЮСШ [1, 4].

Після педагогічного експерименту було виявлено достовірні зміни показників фізичної підготовленості тенісисток у вправах: на швидкість та швидкісно-силові здібності - метання тенісного м'яча на дальність, середній результат підвищився на 39,8\% (t=3,70, $\mathrm{p}<0,01)$ та у хваті гімнастичної палиці, що падає, - на 12,7\% ( $\mathrm{t}=5,00$, $\mathrm{p}<0,001)$; на спритність та швидкісну витривалість у човниковому бігу у 5 напрямах з ракетками «Віяло» результат збільшився на 8,9\% ( $\mathrm{t}=2,40, \mathrm{p}<0,05)$. У інших контрольних вправах були отримані позитивні зміни, але вони не мали достовірних результатів. Так у бігу на 18 м результат підвищився на $18,8 \%(\mathrm{t}=1,10, \mathrm{p}>0,05) ;$ у тесті «стрибок у довжину з місця» на 9,4\% (t=1,50, p>0,05), у

Таблиця 1

Зміни показників фізичної підготовленості тенісисток після педагогічного експерименту (n=12)

\begin{tabular}{|c|c|c|c|c|c|}
\hline \multirow[t]{2}{*}{$\begin{array}{l}\text { No } \\
\text { 3/II }\end{array}$} & \multirow[t]{2}{*}{$\begin{array}{c}\text { Контрольні } \\
\text { вправи }\end{array}$} & $\begin{array}{c}\text { до } \\
\text { експерименту } \\
\mathbf{n}=12 \\
\end{array}$ & $\begin{array}{c}\text { після } \\
\text { експерименту } \\
\mathbf{n}=12 \\
\end{array}$ & \multirow[t]{2}{*}{$\begin{array}{c}\text { Оцінка } \\
\text { достовірності } \\
\mathbf{t} ; \mathbf{p}\end{array}$} & \multirow{2}{*}{$\begin{array}{c}\text { Зміни } \\
\text { показни } \\
\text { ків, } \\
\text { \% }\end{array}$} \\
\hline & & $\bar{X} \pm \boldsymbol{m}$ & $\bar{X} \pm \boldsymbol{m}$ & & \\
\hline 1 & $\begin{array}{l}\text { Метання тенісного } \\
\text { м'яча на дальність (м) }\end{array}$ & $10,3 \pm 0,20$ & $14,4 \pm 1,10$ & $\begin{array}{l}t=3,70 \\
p<0,01\end{array}$ & 39,8 \\
\hline 2 & $\begin{array}{l}\text { Човниковий біг у 5-ти } \\
\text { напрямах з ракетками } \\
\text { «Віяло» (c) }\end{array}$ & $19,2 \pm 0,40$ & $17,5 \pm 0,60$ & $\begin{array}{l}\mathbf{t}=\mathbf{2 , 4 0} \\
\mathbf{p}<\mathbf{0 , 0 5}\end{array}$ & 8,9 \\
\hline 3 & $\begin{array}{l}\text { Стрибок у довжину } 3 \\
\text { місця (см) }\end{array}$ & $131,4 \pm 3,50$ & $143,8 \pm 7,60$ & $\begin{array}{l}\mathrm{t}=1,50 \\
\mathrm{p}>0,05\end{array}$ & 9,4 \\
\hline 4 & Біг 18 м (c) & $4,8 \pm 0,20$ & $3,9 \pm 0,80$ & $\begin{array}{l}t=1,10 \\
p>0,05\end{array}$ & 18,8 \\
\hline 5 & $\begin{array}{l}\text { Хват гімнастичної } \\
\text { палиці, що падає (см) }\end{array}$ & $19,8 \pm 0,40$ & $17,3 \pm 0,30$ & $\begin{aligned} t & =5,00 \\
p & <0,001\end{aligned}$ & 12,7 \\
\hline 6 & $\begin{array}{l}\text { Кидок тенісного м'яча } \\
\text { у квадрати провідною } \\
\text { рукою з } 12 \text { разів } \\
\text { (кількість влучань) }\end{array}$ & $4,8 \pm 0,40$ & $6,1 \pm 0,50$ & $\begin{array}{l}\mathrm{t}=2,00 \\
\mathrm{p}>0,05\end{array}$ & 29,2 \\
\hline
\end{tabular}


Таблиця 2

Зміни показників технічної підготовленості тенісисток після педагогічного експреименту (n=12)

\begin{tabular}{|c|c|c|c|c|c|}
\hline \multirow{3}{*}{$\begin{array}{c}\text { Контрольні } \\
\text { вправи }\end{array}$} & \multirow{3}{*}{$\begin{array}{c}\text { Одиниці } \\
\text { виміру }\end{array}$} & \multicolumn{2}{|c|}{ Показники тестування } & \multirow{3}{*}{$\begin{array}{c}\begin{array}{c}\text { Оцінка } \\
\text { достовірності }\end{array} \\
\text { t; p }\end{array}$} & \multirow{3}{*}{$\begin{array}{c}\text { Зміни } \\
\text { показників } \\
\%\end{array}$} \\
\hline & & $\begin{array}{c}\text { до } \\
\text { експерименту } \\
\mathbf{n}=12 \\
\end{array}$ & $\begin{array}{c}\text { після } \\
\text { експерименту } \\
\mathbf{n = 1 2} \\
\end{array}$ & & \\
\hline & & $\bar{X} \pm \boldsymbol{m}$ & $\bar{X} \pm \boldsymbol{m}$ & & \\
\hline $\begin{array}{l}\text { Удар зльоту } \\
\text { через сітку }\end{array}$ & влучення & $1,3 \pm 0,20$ & $1,6 \pm 0,30$ & $\begin{array}{l}t=0,83 \\
p>0,05\end{array}$ & 23,1 \\
\hline $\begin{array}{c}\text { Удар з } \\
\text { відскоку від } \\
\text { стінки } \\
\end{array}$ & влучення & $10,8 \pm 1,20$ & $14,4 \pm 1,10$ & $\begin{array}{l}\mathbf{t}=\mathbf{2 , 2 0} \\
\mathbf{p}<\mathbf{0 , 0 5}\end{array}$ & 33,3 \\
\hline $\begin{array}{c}\text { Удар з } \\
\text { відскоку } \\
\text { через сітку }\end{array}$ & влучення & $3,9 \pm 0,40$ & $6,1 \pm 0,70$ & $\begin{array}{l}\mathbf{t}=2,70 \\
\mathbf{p}<0,05\end{array}$ & 56,4 \\
\hline $\begin{array}{c}\text { Подача } \\
\text { через сітку }\end{array}$ & влучення & $0,8 \pm 0,30$ & $1,1 \pm 0,70$ & $\begin{array}{l}\mathrm{t}=0,39 \\
\mathrm{p}>0,05\end{array}$ & 37,5 \\
\hline
\end{tabular}

кидку тенісного м'яча у квадрати провідною рукою - на 29,2\% (t=2,00 p>0,05) (табл. 1).

Отримані недостовірні результати в бігу на $18 \mathrm{~m}, \mathrm{y}$ стрибках в довжину з місця та у кидку тенісного м'яча у квадрати провідною рукою вказують на необхідність більше застосовувати вправи для розвитку стартової швидкості і бігу по дистанції, виконання різноманітних стрибків вперед, в сторони, уверх для розвитку швидкісно-силових здібностей і удосконалювати координаційні здібності спортсменок.

У технічній підготовленості отримані достовірні зміни у вправах: в ударах з відскоку від стінки на 33,3\% $(\mathrm{t}=2,20, \mathrm{p}<0,05)$ та в ударах з відскоку через сітку з кошика тренера на $56,4 \%(t=2,70, p<0,05)$. Результати виконання подачі через сітку покращилися на 37,5\% $(\mathrm{t}=0,39)$ та удари зльоту через сітку збільшилися $23,1 \%$ $(t=0,83)$, але не мали достовірних змін $(p>0,05)$ (табл.2).
Аналіз показників технічної підготовленості тенісисток показує, що рівень володіння ракеткою та виконання технічних прийомів з м'ячем покращився, але спортсменкам необхідно розвивати координаційні здібності, такі як здатність до просторово-часової орієнтації, координованість рухів, розвивати почуття м'яча.

Кореляційний аналіз визначив значущі взаємозв'язки показників до педагогічного експерименту (табл. 3). Так, середній рівень зворотних зв'язків виявився між метанням тенісного м'яча на дальність та човниковим бігом «Віяло» $(r=-0,71)$.

Удари з відскоку через сітку мають середні взаємозв'язки зі стрибком в довжину з місця $(r=0,69)$, кидком тенісного м'яча у квадрати провідною рукою $(r=0,77)$ та ударами з відскоку від стінки $(r=0,73)$. Показники подачі корелюють з ударами з відскоку через сітку ( $r=0,67)$.

Таблиця 3

Взаємозв' язки показників технічної та фізичної підготовленості тенісисток до педагогічного експерименту $(n=12)$

\begin{tabular}{|l|l|l|l|l|l|l|l|l|l|l|}
\hline & 1 & 2 & 3 & 4 & 5 & 6 & 7 & 8 & 9 & 10 \\
\hline 1 & 1 & & & & & & & & & \\
\hline 2 & $\mathbf{- 0 , 7 1}$ & 1 & & & & & & & & \\
\hline 3 & 0,51 & $-0,27$ & 1 & & & & & & & \\
\hline 4 & $-0,51$ & 0,41 & $-0,29$ & 1 & & & & & & \\
\hline 5 & $-0,42$ & 0,47 & $-0,36$ & 0,59 & 1 & & & & & \\
\hline 6 & 0,37 & $-0,15$ & $\mathbf{0 , 9 4}$ & $-0,12$ & $-0,14$ & 1 & & & & \\
\hline 7 & 0,18 & $-0,40$ & $-0,18$ & $-0,52$ & $-0,39$ & $-0,21$ & 1 & & & \\
\hline 8 & 0,44 & $-0,58$ & 0,17 & $-0,41$ & $-0,06$ & 0,30 & 0,52 & 1 & & \\
\hline 9 & 0,59 & $-0,49$ & $\mathbf{0 , 6 9}$ & $-0,34$ & $-0,14$ & $\mathbf{0 , 7 7}$ & 0,34 & $\mathbf{0 , 7 3}$ & 1 & \\
\hline 10 & 0,24 & 0,11 & 0,34 & 0,13 & 0,26 & 0,49 & 0,22 & 0,28 & $\mathbf{0 , 6 7}$ & 1 \\
\hline
\end{tabular}

Примітка. 1-6 показники фізичної підготовленості: 1-метання тенісного м'яча на дальність (м); 2- човниковий біг «Віяло» (с); 3- стрибок у довжину з місця; 4-біг 18 м (с); 5- хват гімнастичної палиці, що падає (см); 6- кидок тенісного м'яча у квадрати провідною рукою (влучення);

7-10 показники технічної підготовленості: 7- удар зльоту через сітку (влучення); 8- удар з відскоку від стінки (влучення); 9- удар з відскоку через сітку (влучення); 10- подача через сітку в мішень (влучення). 
Високий рівень значущості показників виявився між кидком тенісного м'яча у квадрати провідною рукою та стрибком в довжину з місця $(r=0,94)$, що вказує на залежність координаційних та швидкісно-силових здібностей для правильного виконання технічної вправи спортсменками.

Після проведення педагогічного експерименту визначилося більше значущіх зв'язків між показниками технічної та спеціальної фізичної підготовленості (табл.4). Середній рівень зв'язків виявлено між показниками: «стрибок у довжину 3 місця» 3 «метанням тенісного м'яча на дальність» $(r=0,63)$ і човниковим бігом «Віяло» $(r=0,60)$, що відповідно вказують на підбір вправ на розвиток швидкісно-силових здібностей спортсменок. Кореляція зв'язків у кидках тенісного м'яча на дальність та кидків тенісного м'яча на влучність $(r=0,72)$ показує покращення виконання елементів подачі тенісистками. Цю думку підтверджують середні взаємозв'язки показників: «виконання подачі 3 метанням м'яча на дальність» $(r=0,73)$ зі «стрибком в довжину з місця» $(r=0,64)$, з «ударами зльоту» $(r=0,69)$ та високий рівень значущості з «ударами з відскоку через сітку» $(r=0,84)$, але цього було недостатньо для достовірності результатів подачі.

Високі та середні зв'язки між ударами зльоту та ударами з відскоку від стінки $(r=0,74)$ та ударами з відскоку через сітку $(r=0,87)$ вказують на підвищення у тенісисток рівня володіння ракеткою, влучності виконання різноманітних ударів. Зворотні кореляційні зв'язки виявлено у показників в хваті гімнастичної палиці, що падає з ударами з відскоку через сітку $(r=-0,72)$ і подачі $(r=-0,66)$, що підкреслює наявність у спортсменок помилок у технічному виконанні ударів. Помилками при виконанні ударів у русі можна пояснити зворотні зв'язки між показниками ударів з відскоку через сітку та бігом на 18 м ( $r=-0,72)$.

\section{Висновки / Дискусія}

Аналіз науково-методичної літератури свідчить про актуальність дослідження. Результати підтверджуються дослідженнями авторів $[2,4,8]$. Також розширені дані вітчизняних $[7,11]$ і закордонних авторів $[13,14,15]$, які займалися питаннями пошуку ефективних методик удосконалення підготовленості спортсменів у тенісі. Результати фізичної підготовленості після проведення педагогічного експерименту виявили недоліки в розвитку стартової швидкості, швидкісно-силової підготовленості та координаційних здібностей тенісисток і визначили необхідність подальшого спрямованого підбору засобів та методів тренування. Необхідність застосування таких вправ на етапі початкової підготовки підкреслювали в своїх працях науковці [2, 3, 9].

Проводячи аналіз результатів технічної підготовленості, достовірні позитивні зміни у тенісисток виявилися в ударах з відскоку від стінки, в ударах 3 відскоку. Правильно підібрані вправи з фізичної підготовки, а саме: розвиток м'язів кисті, передпліччя, ніг та м'язів тулуба, різноманітні переміщення з різних положень зі зміною швидкості виконання, кількістю кроків дали змогу правильно підходити до виконання удару, добре тримати ракетку і покращити результати тестування в ударах. Недостатня точність попадання подачі та ударів зльоту вплинула на недостовірні зміни результатів тестування. При виконанні всіх вправ тренер вимагав від тенісисток не тільки влучного попадання в ціль, а також правильного виконання технічного прийому. Отримані результати підтверджуються дослідженнями авторів $[1,4,8,11]$.

Первинне педагогічне тестування виявило, що показники мають задовільні результати для цього віку відповідно з нормативами ДЮСШ.

Таблиця 4

Взаємозв'язки показників технічної та фізичної підготовленості тенісисток після педагогічного експерименту $(n=12)$

\begin{tabular}{|l|r|r|r|r|r|r|r|r|r|r|}
\hline Показники & 1 & 2 & 3 & 4 & 5 & 6 & 7 & 8 & 9 & 10 \\
\hline 1 & 1 & & & & & & & & & \\
\hline 2 & 0,16 & 1 & & & & & & & & \\
\hline 3 & $\mathbf{0 , 6 3}$ & $\mathbf{0 , 6 0}$ & 1 & & & & & & & \\
\hline 4 & $-0,27$ & 0,15 & $-0,06$ & 1 & & & & & & \\
\hline 5 & $-0,45$ & 0,25 & $-0,38$ & 0,37 & 1 & & & & & \\
\hline 6 & $\mathbf{0 , 7 2}$ & $-0,09$ & 0,31 & $-0,25$ & $-0,59$ & 1 & & & & \\
\hline 7 & 0,21 & 0,18 & 0,43 & & $-0,49$ & 0,04 & 1 & & & \\
\hline 8 & 0,34 & 0,21 & 0,49 & $-0,51$ & $-0,46$ & 0,45 & $\mathbf{0 , 7 4}$ & 1 & & \\
\hline 9 & 0,40 & $-0,14$ & 0,29 & $\mathbf{- 0 , 7 1}$ & $\mathbf{- 0 , 7 2}$ & 0,28 & $\mathbf{0 , 8 7}$ & $\mathbf{0 , 6 8}$ & & \\
\hline 10 & $\mathbf{0 , 7 3}$ & 0,13 & $\mathbf{0 , 6 6}$ & $-0,41$ & $\mathbf{- 0 , 6 6}$ & 0,38 & $\mathbf{0 , 6 9}$ & 0,58 & $\mathbf{0 , 8 4}$ & \\
\hline
\end{tabular}

Примітка. 1-6 показники фізичної підготовленості: 1-метання тенісного м'яча на дальність (м); 2- човниковий біг «Віяло» (c); 3- стрибок у довжину з місця; 4-біг 18 м (с); 5- хват гімнастичної палиці, що падає (см); 6- кидок тенісного м'яча у квадрати провідною рукою (влучення);

7-10 показники технічної підготовленості: 7- удар зльоту через сітку (влучення); 8- удар з відскоку від стінки (влучення); 9- удар з відскоку через сітку (влучення); 10- подача через сітку в мішень (влучення). 


\section{СЛОБОЖАНСЬКИЙ НАУКОВО-СПОРТИВНИЙ ВІСНИК}

Застосована методика комплексного розвитку фізичних якостей та технічної підготовленості за програмою ДЮСШ сприяла достовірним позитивним змінам показників фізичної підготовленості тенісисток у метанні тенісного м'яча на дальність на 39,8\% ( $\mathrm{t}=3,70$, $\mathrm{p}<0,01)$, у хваті гімнастичної палиці, що падає, на $12,7 \%$ $(\mathrm{t}=5,00, \mathrm{p}<0,001)$, у човниковому бігу у 5 напрямах 3 ракетками «Віяло» на 8,9\% ( $\mathrm{t}=2,40, \mathrm{p}<0,05)$. В інших контрольних вправах були отримані позитивні зміни, але вони не мали достовірних результатів ( $p>0,05)$.

У технічній підготовленості отримані позитивні достовірні зміни у вправах: в ударах з відскоку від стінки на $33,3 \%(t=2,20, p<0,05)$ та в ударах з відскоку через сітку з кошика тренера на 56,4\% $(\mathrm{t}=2,70, \mathrm{p}<0,05)$.

Кореляційний аналіз після проведення педагогічного експерименту підтвердив взаємозв'язки показників фізичної та технічної підготовленості. Виявлено, що по- кращення показників у стрибках в довжину, метання тенісного м'яча на дальність і точність сприяло підвищенню значимості зв'язків до середнього та високого рівнів показників в ударах з відскоку від стінки та через сітку, а також в подачі.

Таким чином, можна визначити, що впровадження методики комплексного розвитку фізичних якостей та технічної підготовленості за програмою ДЮСШ сприяла достовірним змінам показників. Визначилися шляхи для подальшого удосконалення швидкісних, швидкісно-силових та координаційних здібностей, подачі та ударам по м'ячу тенісисток.

Перспективи подальших досліджень. Виходячи з вищенаведеного, подальші дослідження планується проводити у напрямку визначення впливу психофізичних здібностей на техніко-тактичні показники підготовленості тенісисток на етапі початкової підготовки.

Конфлікт інтересів. Автори заявляють, що немає конфлікту інтересів, який може сприйматися як такий, що може завдати шкоди неупередженості статті.

Джерела фінансування. Ця стаття не отримала фінансової підтримки від державної, громадської або комерційної організації.

\section{Список посилань}

1. Белиц-Гейман С.П. (2001), Теннис: школа чемпионов, игры и подготовка. Москва: АСТ-ПРЕСС, 223 с.

2. Гринченко І. Б., Куликов В. В., Чичін Д. С., Даниленко О. М. (2019), «Динаміка фізичної та технічної підготовленості юних тенісистів 7-8 років на етапі початкової підготовки», Технології збереження здоров'я, реабілітація і фізична терапія: збірник статей XII міжнародної наукової конференції, 07 листопада 2019 р. Харків - Торунь. С. 41 - 47.

3. Жуков С. М., Лукачіна А. В. (2014), «Вибір тренувальних вправ у тенісі», Ключови въпроси в съвременната наука: Материали за 10-а международна научна практична конференция. Том 38. Технологии. Физическа култура и спорт. София: «Бял ГРАД-БГ» ООД, С. 60-63.

4. Ібраімова М. В., Ханюкова О. В. (2014), «Особливості контрольних випробувань юних тенісистів 6-7 років на початковому етапі навчання», Фізична культура, спорт та здоров'я : матеріали XIV Міжнародної конференції (Харків, 10-12 грудня 2014 р.). Харків : ХДАФК, С. 81-84.

5. Ібраімова М. В. (2012), Теніс: Навчальна програма для дитячо-юнацьких спортивних шкіл, спеціалізованих дитячоюнацьких шкіл олімпійського резерву, шкіл вищої спортивної майстерності та спеціалізованих навчальних закладів спортивного профілю. К.: РНМК, 158c.

6. Креспо М., Рейд М. (2013), Подготовка юных теннисистов: учебно-методическое пособие для тренеров. Валенсия: изд-во МФТ, $320 \mathrm{c}$.

7. Лазарчук О. (2008), «Визначення рівня спеціальних фізичних здібностей майбутніх тенісистів», Фізичне виховання, спорт і культура здоров'я у сучасному суспільстві. Том 3, С.248-251.

8. Лобода В. С., Мулик В. В. (2012), «Визначення взаємозв'язку морфологічних показників окремих рухових якостей і виконання елементів техніки юних тенісистів 6-8 років», Фізичне виховання, спорт і культура здоров'я у сучасному суспільстві. Том 3(19), С. 354-358.

9. Скородумова А. П., Баранов И. С., Кузнецова О. В. (2018), «Особенности физической подготовленности теннисистов 6-8 лет», Вестник спортивной науки. №5. URL: https://cyberleninka.ru/article/n/osobennosti-fizicheskoy-podgotovlennostitennisistov-6-8-let (дата звернення: 15.05.2021).

10. Сушко Р. О., Ібраімова М. В. (2015), «Інноваційні технології у початковій підготовці дітей на прикладі спортивних ігор», Слобожанський науково-спортивний вісник, № 2(46), С.190-194.

11. Ханюкова О. В. (2015), «Аналіз впливу методики планування навчально-тренувального процесу на рівень оволодіння технічними навичками тенісистів першого року навчання», Науковий часопис НПУ імені МП Драгоманова. Серія 15: Науковопедагогічні проблеми фізичної культури (фізична культура і спорт). Вип. 11, С. 156-160.

12. Шевченко О. (2019), «Зміна рівня показників техніко-тактичної підготовленості у тенісистів на етапі попередньої базової підготовки», Слобожанський науково-спортивний вісник, № 1 (69), С. 54-57.

13. Education H., Snelleman L. (1993), «Speed training related to coordination, anticipation, footwork and concentration», ITF Coaching and Sport Science Review, No. 1, pp.8-9.

14. Vilches F. (2015), «An athlete's long term development. The integral preparation of the developing player», Coaching and Sport Science Review, No. 66, pp. 5-6.

15. Gonzalez R. (2012), «Tennis 10s: adapting coaching methodology to the rule change», Coaching \& Sport Science Review, Issue. 57, pp. 23-24.

Стаття надійшла до редакції: 05.05.2021 р.

Опубліковано: 23.06.2021 p. 


\begin{abstract}
Аннотация. Олег Шевченко, Святослав Коваль, Максим Мерзликин. Комплексное развитие технической и физической подготовленности теннисисток 7-8 лет. Цель: исследовать изменения показателей технической и физической подготовленности теннисисток 7-8 лет под влиянием занятий по программе ДЮСШ. Материалы и методы: теоретический анализ и обобщение научно-методических литературных источников; тестирование технической и физической подготовленности, педагогический эксперимент, методы математической статистики. В исследовании принимали участие 12 девочек возрастом 7-8 лет группы начальной подготовки 2 года обучения. Результаты: получены достоверные изменения показателей физической подготовленности в броске теннисного мяча на дальность - 39,8\% $(t=3,70, p<0,01)$, в упражнении ловля палки, которая падает - на 12,7\% ( $t=5,00, p<0,001)$, челночного бега в 5-ти направлениях с ракетками на 8,9\% $(t=2,40, p<0,05)$. $B$ других контрольных упражнениях были получены положительные изменения, но они не имели достоверных результатов ( $p>0,05)$. В технической подготовленности получены достоверные изменения в ударах с отскока от стенки на $33,3 \%(t=2,20, p<0,05)$ и ударах с отскока после набрасывания тренера $-56,4 \%(t=2,70, p<0,05)$. Правильно подобранные упражнения по физической подготовке дали возможность теннисисткам своевременно подходить к мячу для выполнения удара и улучшить результаты тестирования. Выявлено, что после педагогического эксперимента улучшение показникателей в прыжках в длину, в метании теннисного мяча на дальность и точность способствовало повышению значимости корреляционных связей до среднего и высокого уровней показателей в ударах с отскока от стенки и через сетку, в подаче. Выводы: внедрение методики комплексного развития физических качеств и технической подготовленности повлияло на достоверные изменения показателей. Определено пути для дальнейшего совершенствования скоростных, скоростно-силовых и координационных способностей, подачи, ударов по мячу теннисисток.
\end{abstract}

Ключевые слова: теннисистки, физическая подготовленность, показатели, технические приёмы.

Abstract. Oleg Shevchenko, Svyatoslav Koval, Maksym Merzlikin. Integrated development of technical and physical preparedness of 7-8-years-old female tennis players. Purpose: to research changes in technical and physical preparedness of 7-8-year-old sportswomen under the influence of classes on the program of CYSS. Material and methods: theoretical analysis and generalization of scientific and methodological literary sources; testing of technical and physical fitness, pedagogical experiment, methods of mathematical statistics. The research involved 7-8-year-old girls in the initial training group of the second year of study. Results: reliable changes in physical preparedness in in throwing a tennis ball to the range - by $39,8 \%(t=3,70, p<0,01)$, in the exercise of catching a falling stick - by $12,7 \%(t=5,00, p<0,001)$; the shuttle run in 5 directions with rackets "Fan" - by $8,9 \%(t=2,40, p<0,05)$. Positive changes were obtained but had no valid results in other control exercises $(p>0,05)$. In technical preparation, positive reliable changes in exercises were obtained: in impacts from the rebound from the wall by $33,3 \%(t=2,20, p<0,05)$ and in impacts from the rebound through the grid from the coach basket by $56,4 \%(t=2,70, p<0,05)$. Correctly selected physical fitness exercises allowed the tennis players to approach the ball in time to hit the ball and improve the test results. It was revealed that the improvement in indicators in long jump, throwing a tennis ball at a range and accuracy contributed to an increase in the importance of correlation links to an average and high level of indicators in hits from the rebound from the wall and through the net, in serve. Conclusions: the introduction of the methods for the integrated development of physical qualities and technical preparedness under the program of CYSS contributed to reliable changes in indicators. Ways were determined for the further improvement of speed and high-speed and power abilities, serving, and strokes of female tennis players.

Keywords: female tennis players, physical preparedness, indicators, techniques.

\title{
References
}

1. Belits-Geyman, S. P. (2001), Tennis: shkola chempionov, igryi i podgotovka. Moskva: AST-PRESS, 223 p. (in Russ.).

2. Hrynchenko, I. B., Kulykov, V. V., Chychin, D. S., Danylenko, O. M. (2019), «Dynamics of physical and technical fitness of young tennis players 7-8 years old at the stage of initial training», Tekhnolohii zberezhennia zdorovia, reabilitatsiia i fizychna terapiia: zbirnyk statei XII mizhnarodnoi naukovoi konferentsii, 07 lystopada 2019 r. Kharkiv - Torun. pp. 41 - 47. (in Ukr.).

3. Zhukov, S. M., Lukachina, A. V. (2014), « Choice of training exercises in tennis», Kliuchovy vъprosy v sъvremennata nauka: Materyaly za 10-a mezhdunarodna nauchna praktychna konferentsyia. Tom 38. Tekhnolohyy. Fyzycheska kultura y sport. Sofyia: «Bial HRAD-BH»OOD, pp. 60-63. (in Ukr.).

4. Ibraimova, M. V., Khaniukova, О. V. (2014), «Особливості контрольних випробувань юних тенісистів 6-7 років на початковому етапі навчання", Fizychna kultura, sport ta zdorovia : materialy KhIV Mizhnarodnoi konferentsii (Kharkiv, 10-12 hrudnia 2014 r.). Kharkiv : KhDAFK, pp. 81-84. (in Ukr.).

5. Ibraimova, M. V. (2012), Tenis: Navchalna prohrama dlia dytiacho-yunatskykh sportyvnykh shkil, spetsializovanykh dytiachoyunatskykh shkil olimpiiskoho rezervu, shkil vyshchoi sportyvnoi maisternosti ta spetsializovanykh navchalnykh zakladiv sportyvnoho profiliu. K.: RNMK, 158 p. (in Ukr.).

6. Krespo, M., Reyd, M. (2013), Podgotovka yunyih tennisistov: uchebno-metodicheskoe posobie dlya trenerov. Valensiya: izdvo MFT, 320 p. (in Russ.).

7. Lazarchuk, O. (2008), «Determining the level of special physical abilities of future tennis players», Fizychne vykhovannia, sport i kultura zdorovia u suchasnomu suspilstvi. Tom 3, pp .248-251. (in Ukr.).

8. Loboda, V. S., Mulyk, V. V. (2012), «Determination of the relationship of morphological indicators of individual motor qualities and performance of technical elements of young tennis players 6-8 years», Fizychne vykhovannia, sport i kultura zdorovia u suchasnomu suspilstvi. Tom 3(19), pp. 354-358. (in Ukr.).

9. Skorodumova, A. P., Baranov, I. S., Kuznetsova, O. V. (2018), «Features of physical fitness of tennis players 6-8 years old», Vestnik sportivnoy nauki. No. 5. aviable at: https://cyberleninka.ru/article/n/osobennosti-fizicheskoy-podgotovlennosti-tennisistov-68-let (in Russ.).

10. Sushko, R. O., Ibraimova, M. V. (2015), «Innovative technologies in the initial training of children on the example of sports games», Slobozhanskyi naukovo-sportyvnyi visnyk, № 2(46), pp.190-194. (in Ukr.).

11. Khaniukova, O. V. (2015), «Analysis of the impact of the methodology of planning the training process on the level of mastering the technical skills of tennis players in the first year of study", Naukovyi chasopys NPU imeni MP Drahomanova. Seriia 15: Naukovopedahohichni problemy fizychnoi kultury (fizychna kultura i sport). Vyp. 11, pp. 156-160. (in Ukr.).

12. Shevchenko, O. (2019), "Changing the level of indicators of technical and tactical readiness of tennis players at the stage of preliminary basic training», Slobozhanskyi naukovo-sportyvnyi visnyk, № 1 (69), pp. 54-57. (in Ukr.). 


\section{СЛОБОЖАНСЬКИЙ НАУКОВО-СПОРТИВНИЙ ВІСНИК}

13. Education, H., Snelleman, L. (1993), «Speed training related to coordination, anticipation, footwork and concentration», ITF Coaching and Sport Science Review, No. 1, pp.8-9. (in Eng.).

14. Vilches, F. (2015), "An athlete's long term development. The integral preparation of the developing player», Coaching and Sport Science Review, No. 66, pp. 5-6. (in Eng.).

15. Gonzalez, R. (2012), «Tennis 10s: adapting coaching methodology to the rule change», Coaching \& Sport Science Review, Issue. 57, pp. 23-24. (in Eng.).

Received: 05.05.2021.

Published: 23.06.2021.

\section{Відомості про авторів / Information about the Authors}

Шевченко Олег Олександрович: к. фіз. вих., доцент; Харківська державна академія фізичної культури: вул. Клочківська, 99, м. Харків, 61058, Україна.

Шевченко Олег Александрович: к.физ.восп., доцент; Харьковская государственная академия физической культуры: ул.Клочковская, 99, г. Харьков, 61058, Украина.

Oleg Shevchenko: PhD (Physical Education and Sport), Associate Professor; Kharkiv State Academy of Physical Culture: Klochkivskastreet 99, Kharkiv, 61058, Ukraine.

\section{ORCID: https://orcid.org/0000-0002-2856-9640}

E-mail: Shevchenko7777oleg@gmail.com

Коваль Святослав Святославович: к.фіз.вих., доцент; Харківська державна академія фізичної культури: вул. Клочківська 99, Харків, 61058, Україна.

Коваль Святослав Святославович: к.физ.восп., доцент; Харьковская государственная академия физической культуры: ул. Клочковская 99, г. Харьков, 61058, Украина.

Svyatoslav Koval: PhD (Physical Education and Sport), Associate Professor; Kharkiv State Academy of Physical Culture: Klochkivskastreet 99, Kharkiv, 61058, Ukraine.

\section{ORCID: https://orcid.org/0000-0001-7140-6276}

E-mail: Koval.S.S.79@gmail.ru

Мерзлікін Максим Вячеславович: Харківська державна академія фізичної культури: вул.Клочківська, 99, м. Харків, 61058, Україна.

Мерзликин Максим Вячеславович: Харьковская государственная академия физической культуры: ул. Клочковская, 99, г. Харьков, 61058, Украина.

Maksym Merzlikin: Kharkiv State Academy of Physical Culture: Klochkivskastreet 99, Kharkiv, 61058, Ukraine.

ORCID: https://orcid.org/0000-0002-8798-1002

E-mail: merzlikin80@mail.ua 